\title{
Antibodies to Human Growth Hormone (HGH) in Human Subjects Treated with $\mathrm{HGH}$ *
}

\author{
Jesse Roth, Seymour M. Glick, Rosalyn S. Yalow, and \\ SOLOMON A. BERSON \\ (From the Radioisotope Service, Veterans Administration Hospital, Bronx, N. Y.)
}

Human growth hormone (HGH) $(1,2)$ has been used experimentally and therapeutically in man since 1957 (3-5). The metabolic and growth-promoting effects of the parenterally administered hormone in humans (3-5) and the antigenicity of various $\mathrm{HGH}$ preparations in rabbits and in guinea pigs $(6,7)$ are well documented.

This paper describes the appearance of specific antibodies to HGH in the plasma of human subjects treated with $\mathrm{HGH}$.

\section{Methods}

Purified HGH from several sources was dissolved in sterile normal saline with the addition of a few drops of $0.1 \mathrm{~N} \mathrm{HCl}$ (HGH of Raben and of Elrick) or $0.1 \mathrm{~N}$ $\mathrm{NaOH}$ (HGH of Wilhelmi and of Elrick), and was administered intramuscularly daily for several weeks to two normal adult male volunteers. In addition, a number of sera from children who had been treated with $\mathrm{HGH}$ for retarded growth was supplied by other investigators. The growth hormone preparations used by these investigators had been passed through a Seitz filter before injection.

HGH (Raben \#6 or Wilhelmi HS 372B) was labeled with $\mathrm{I}^{131}$ by the method of Hunter and Greenwood (8) to a specific activity of 200 to $500 \mathrm{mc}$ per $\mathrm{mg}$.

A small but variable (about 15 to $35 \%$ ) fraction of the labeled hormone becomes damaged during the labeling process ("preparation damage") and binds nonspecifically to plasma proteins in nonimmune ("control") serum. The conclusion that this fraction is damaged is derived principally from observations that this fraction is increased as the specific activity of the labeled hormone is increased. Paper electrophoresis of mixtures of unpurified HGH-I $\mathrm{I}^{121}$ and rabbit anti-HGH antiserums reveals that all the nondamaged $\mathrm{HGH}-\mathrm{I}^{131}$ binds to antibody. The HGH-I ${ }^{131}$ can be largely or almost entirely freed of damaged components by purification on starch gel electrophoresis (9). HGH-I ${ }^{131}$ eluted from the pre-

* Submitted for publication October 31, 1963; accepted January 23, 1964.

Presented in part to the American Federation for Clinical Research, December 13, 1963 (Clin. Res. 1963, $11,402$. albumin zone usually contains less than $5 \%$ damaged components.

During incubation with immune or nonimmune plasma a fraction of the purified HGH-I ${ }^{131}$ becomes damaged ("incubation damage"). This phenomenon is characterized by the appearance of labeled fragments that bind nonspecifically to certain plasma proteins, primarily $\alpha$ - and $\beta$-globulins, and by the release of a small amount of $\mathrm{I}^{131}$ as iodide. Similar observations have been reported with insulin- $\mathrm{I}^{131}(10)$. Binding of damaged fractions to $\alpha$ - and $\beta$-globulins cannot be reversed by the addition of high concentrations of unlabeled $\mathrm{HGH}$ and is relatively unaffected by the presence of moderately high concentrations of $\mathrm{HGH}$ at onset of incubation. The factors responsible for damage are not known, but the addition of diisopropyl fluorophosphate (to inhibit enzymatic activity in plasma) is ineffective in preventing damage. $\mathrm{HGH}$ contains disulfide groups which might be subject to reductive splitting by $-\mathrm{SH}$ groups in plasma, a process previously suggested as a cause of damage to insulin- ${ }^{131}$ in plasma (11).

Plasma to be tested for the presence of antibody was diluted $1: 5$ in Veronal buffer $(0.1 \mathrm{M}, \mathrm{pH} 8.6)$ containing human serum albumin $(5 \mathrm{mg}$ per $\mathrm{ml}$ ) and incubated with a tracer quantity of HGH-I ${ }^{131}$ (HGH concentration, approximately $1 \mathrm{~m} \mu \mathrm{g}$ per $\mathrm{ml}$ ) for 4 to 10 days at $4^{\circ} \mathrm{C}$. To separate antibody-bound HGH-I $\mathrm{I}^{121}$ from free (unbound) HGH-I ${ }^{131}$, samples of the incubation mixtures were applied to DEAE paper strips for chromatoelectrophoresis (10) (Veronal buffer, $0.1 \mathrm{M}, \mathrm{pH} 8.6$ at $500 \mathrm{v}$ for 2 hours) or to Whatman $3 \mathrm{MM}$ filter paper for electrophoresis (Veronal buffer, $0.025 \mathrm{M}, \mathrm{pH} 8.6$, at $600 \mathrm{v}$ for 6 hours). The strips were dried in an oven and scanned for radioactivity in an automatic strip counter. In both systems described, free HGH-I ${ }^{131}$ is adsorbed to the paper at the site of application, whereas $\mathrm{HGH}-\mathrm{I}^{131}$ bound to antibody migrates with the $\gamma$ - or inter $\beta-\gamma$-globulins.

Antibody-bound HGH-I $\mathrm{I}^{131}$ is readily distinguished from damaged fractions bound to $\alpha$ - and $\beta$-globulins by the use of conventional paper electrophoresis, but not by chromatoelectrophoresis. Therefore, to determine by chromatoelectrophoresis the percentage of $\mathrm{HGH}-\mathrm{I}^{131}$ bound to antibody, control mixtures containing nonimmune plasma are incubated simultaneously to permit correction for damaged components migrating nonspecifically with serum proteins. In the experiments reported here, approximately $10 \%$ of $\mathrm{HGH}-\mathrm{I}^{131}$ became bound 
nonspecifically to plasma proteins during incubation and was corrected for. In spite of the better resolution of antibody-bound $\mathrm{HGH}-\mathrm{I}^{131}$ from damaged fractions on electrophoresis, chromatoelectrophoresis offers the following advantages: 1) better resolution of bound from free $\mathrm{HGH}-\mathrm{I}^{131}$ and 2) much faster resolution of the fractions; dissociation of antigen-antibody complexes is thereby minimized.

The binding capacity of plasma antibodies for $\mathrm{HGH}$ was evaluated by a method similar to that described for insulin (10). A series of mixtures was prepared, each containing a trace of HGH-I ${ }^{131}$, a $1: 5$ dilution of the patient's plasma, and unlabeled $\mathrm{HGH}$ in concentrations of $10 \mathrm{~m} \mu \mathrm{g}$ per $\mathrm{ml}$ to $1,000 \mathrm{~m} \mu \mathrm{g}$ per $\mathrm{ml}$. After 4 to 10 days of incubation, the mixtures were analyzed by chromatoelectrophoresis on DEAE paper strips; the ratio $(B / F)$ of antibody-bound HGH-I ${ }^{131}$ (B) to free $\mathrm{HGH}-\mathrm{I}^{131}$ (F) was determined for each concentration, after correction for the damaged fraction as described previously for insulin- $\mathrm{I}^{131}(12)$. The quantity of unlabeled HGH bound to antibody was calculated as the product of $\mathrm{HGH}$ concentration and percentage of $\mathrm{HGH}-\mathrm{I}^{131}$ bound to anti-
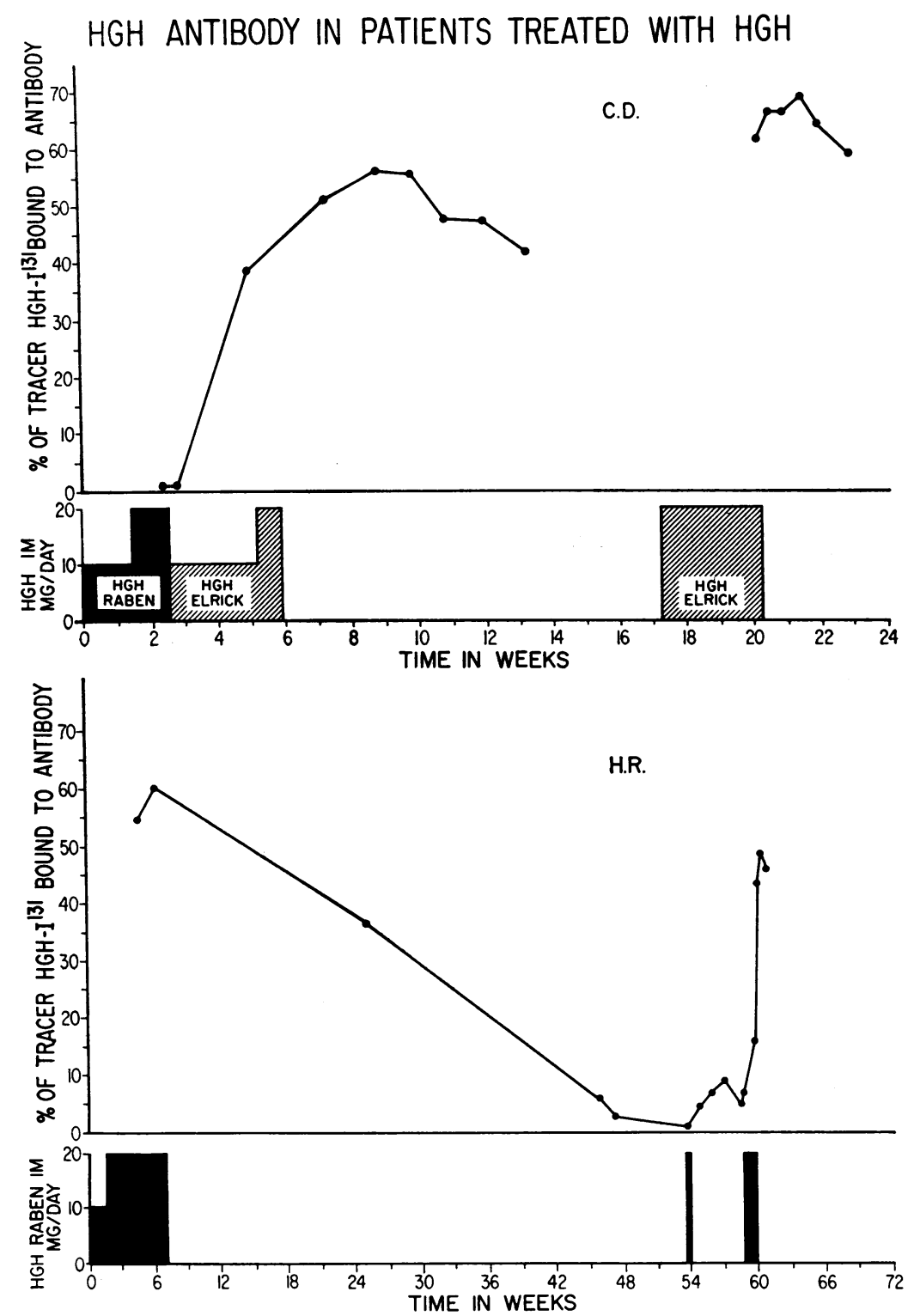

Fig. 1. Binding OF tRACE QUANTITIES OF HUMAN GROWTH HORMONE (HGH)$I^{131}$ BY ANTibodies IN PLASMa (DILUted 1:5) DURING HGH THERAPY. See text for details. 

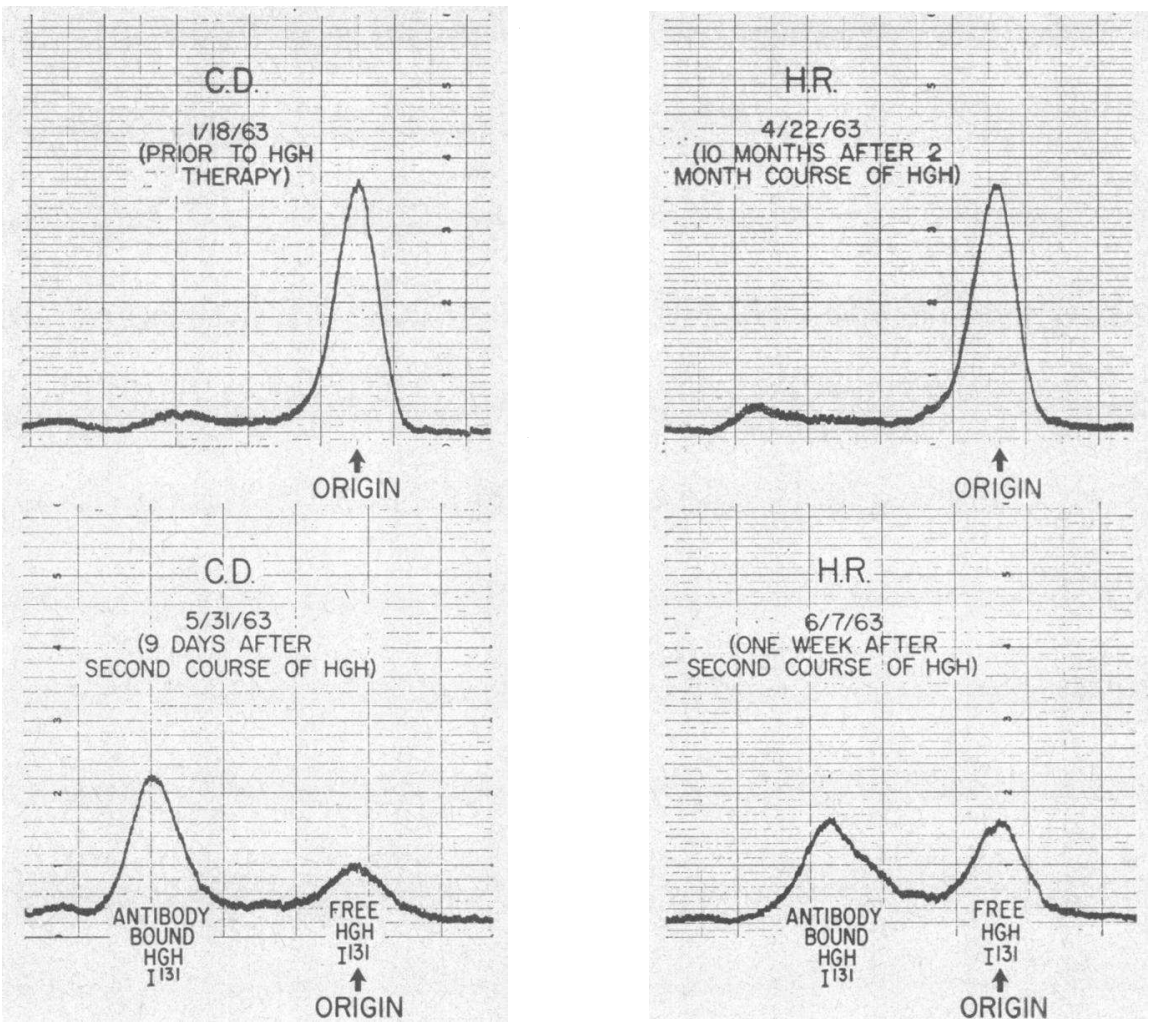

Fig. 2. Chromatoelectrophoretograms (DEAE paper) of HGH-I ${ }^{131}$ IN PLASMa Diluted 1:5 (9 DAYS InCUBation at $4^{\circ} \mathrm{C}$ ). Direction of migration is from right to left. Small peak of migrating radioactivity in C. D. before therapy represents damaged HGH-I ${ }^{131}$ (see text).

body. The $\mathrm{B} / \mathrm{F}$ ratio was plotted as a function of unlabeled hormone bound. Extrapolation of the curve to a $\mathrm{B} / \mathrm{F}$ ratio of zero yields the binding capacity.

Incubated mixtures of plasma and $\mathrm{HGH}-\mathrm{I}^{181}$ with or without added unlabeled HGH were analyzed by immunodiffusion (13) and microimmunoelectrophoresis (14) in agar gel. The challenging antisera were horse or rabbit antihuman whole serum or rabbit antihuman $\gamma$-globulin. After the development of visible precipitin bands the slides were dried, radioautographed, and stained with amido black.

For immunoprecipitation experiments in test tubes (15), rabbit antihuman $\gamma$-globulin in marked excess was added to previously incubated mixtures of plasma and HGH-I ${ }^{131}$ (with or without added unlabeled HGH). After further incubation at room temperature for 2 hours, and then at $4^{\circ} \mathrm{C}$ for 18 hours, the mixtures were centrifuged; the supernatant solution was removed, and the precipitates were resuspended and washed with cold normal saline. Precipitates, supernatant solutions, and washes were assayed separately for radioactivity in a well scintillation counter.

\section{Results}

In the two adults without known pituitary disease, the repeated parenteral administration of
HGH was associated, within 30 to 60 days, with the appearance in plasma of a $\gamma$ - or inter $\beta$ - $\gamma$ globulin that binds HGH-I ${ }^{131}$ (Figures 1 and 2). Cessation of therapy resulted in a slow fall, and resumption of therapy was followed by a rapid rise in concentration of this HGH-binding globulin. ${ }^{1}$ HGH-binding globulins were also detected in the plasma from three of four children who had been treated with $\mathrm{HGH}$ for prolonged periods of time for retarded growth (Figure 3, Table I). In none of several hundred patients not treated with $\mathrm{HGH}$ was antibody detectable by chromatoelectrophoresis or electrophoresis on paper.

Immunodiffusion and microimmunoelectrophore-

1 The percentage of tracer HGH-I ${ }^{131}$ that binds to antibody is not a direct measure of antibody concentration but reflects both antibody concentration and relative affinity of antibody for antigen. The observed changes in the percentage of $\mathrm{HGH}-\mathrm{I}^{131}$ tracer bound to antibody in serum of an individual patient, however, are probably a reflection of changes in concentration of antibody. 

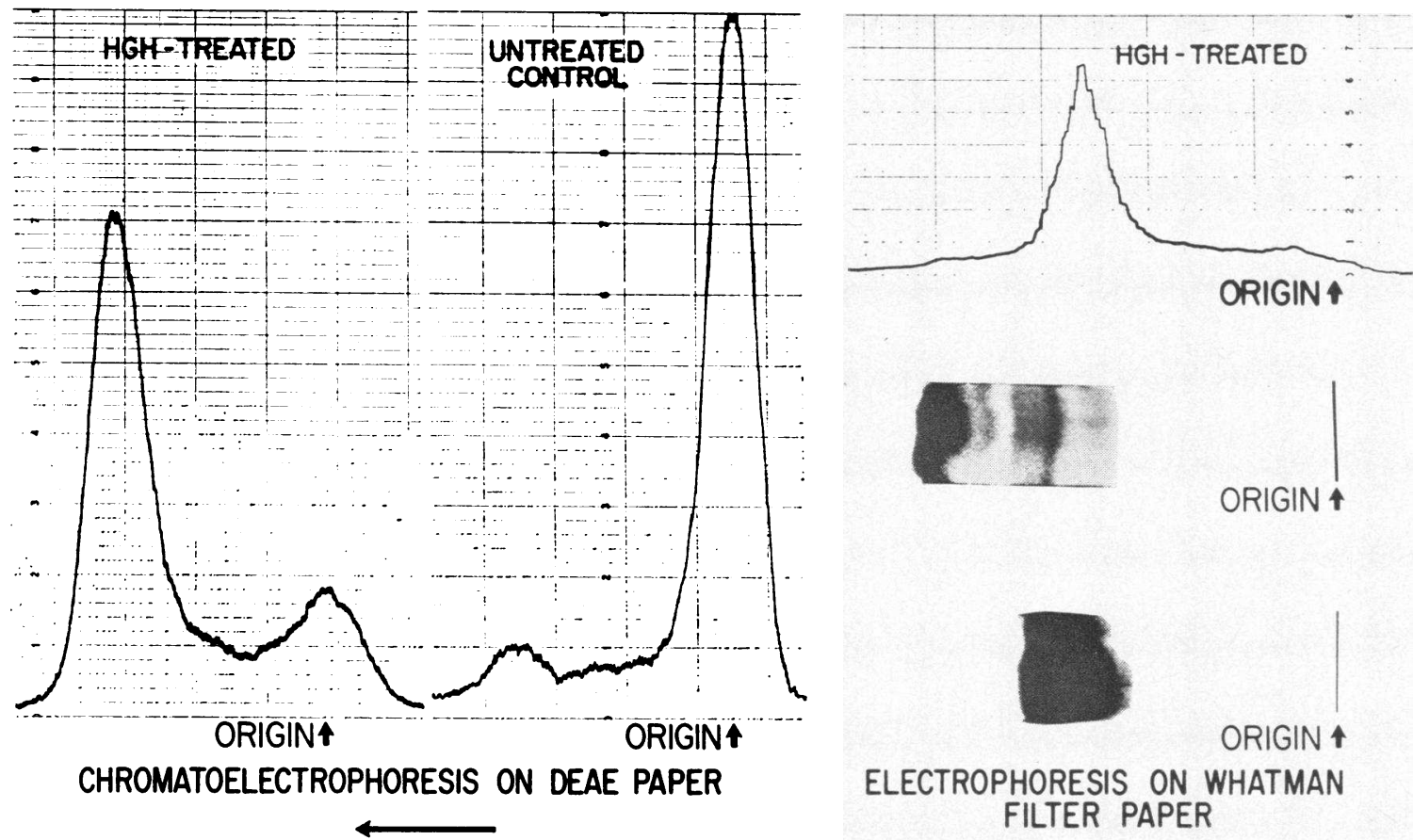

Fig. 3. Binding of HGH-I ${ }^{131}$ to antibodies in plasma of a child (A. W.) treated with HGH. On right are scan of radioactivity on paper strip (top), strip stained with amido black (middle), and radioautograph of strip (bottom). Radioactive peak is in inter $\beta-\gamma$ region. On left chromatoelectrophoretograms of $H G H-I^{131}$ in plasma from A. W. and from an untreated control subject are compared. Small peak of migrating radioactivity in untreated control represents damaged $\mathrm{HGH}-\mathrm{I}^{131}$.

sis showed significantly greater precipitation of radioactivity in the $\gamma$-globulin region with plasmas obtained after a course of therapy with $\mathrm{HGH}$ (Figures 4 and 5). Similarly, immunoprecipitation showed significant precipitation of radioac- tivity only with plasma obtained after therapy with HGH (Table II). That more than $50 \%$ of the tracer HGH-I ${ }^{131}$ was not precipitated in this system is due to the addition of a large volume of antihuman $\gamma$-globulin to produce precipitation,

TABLE I

Data pertaining to human growth hormone (HGH) antigenicity

\begin{tabular}{|c|c|c|c|c|}
\hline \multirow[b]{2}{*}{ Patient } & \multicolumn{2}{|c|}{ HGH therapy } & \multirow{2}{*}{$\begin{array}{c}\text { Presence } \\
\text { of } \\
\text { antibody }\end{array}$} & \multirow{2}{*}{$\underset{\text { capacity }}{\mathrm{HGH}-* \text { binding }}$} \\
\hline & Duration & Dose (im) & & \\
\hline C.D. & 6 weeks & $10-20 \mathrm{mg} /$ day & + & $0.3 \mu \mathrm{g} / \mathrm{ml}$ \\
\hline H.R. & 7 weeks & $10-20 \mathrm{mg} /$ day & + & $0.5 \mu \mathrm{g} / \mathrm{ml}$ \\
\hline A.W. & 4 months & $2 \mathrm{mg} 3$ times/week & + & $4 \mu \mathrm{g} / \mathrm{ml}$ \\
\hline \multirow[t]{2}{*}{ N.C. } & 45 months & $\begin{array}{l}2 \mathrm{mg} 3 \text { times/week for } \\
32 \text { months }\end{array}$ & $? \dagger$ & \\
\hline & & $\begin{array}{l}4 \mathrm{mg} 3 \text { times/week for } \\
13 \text { months }\end{array}$ & & \\
\hline E.L. & 7 months & $2 \mathrm{mg} 3$ times/week & + & Not measured \\
\hline V.O. & 7 months & $2.5 \mathrm{mg} 3$ times/week & + & Not measured \\
\hline
\end{tabular}

* Raben homo \#6 used as standard HGH

+ The amount of $\mathrm{HGH}-\mathrm{I}^{131}$ bound to $\gamma$-globulin in this serum was so slight $(<5 \%)$ that the presence of antibody could not be definitely established. 


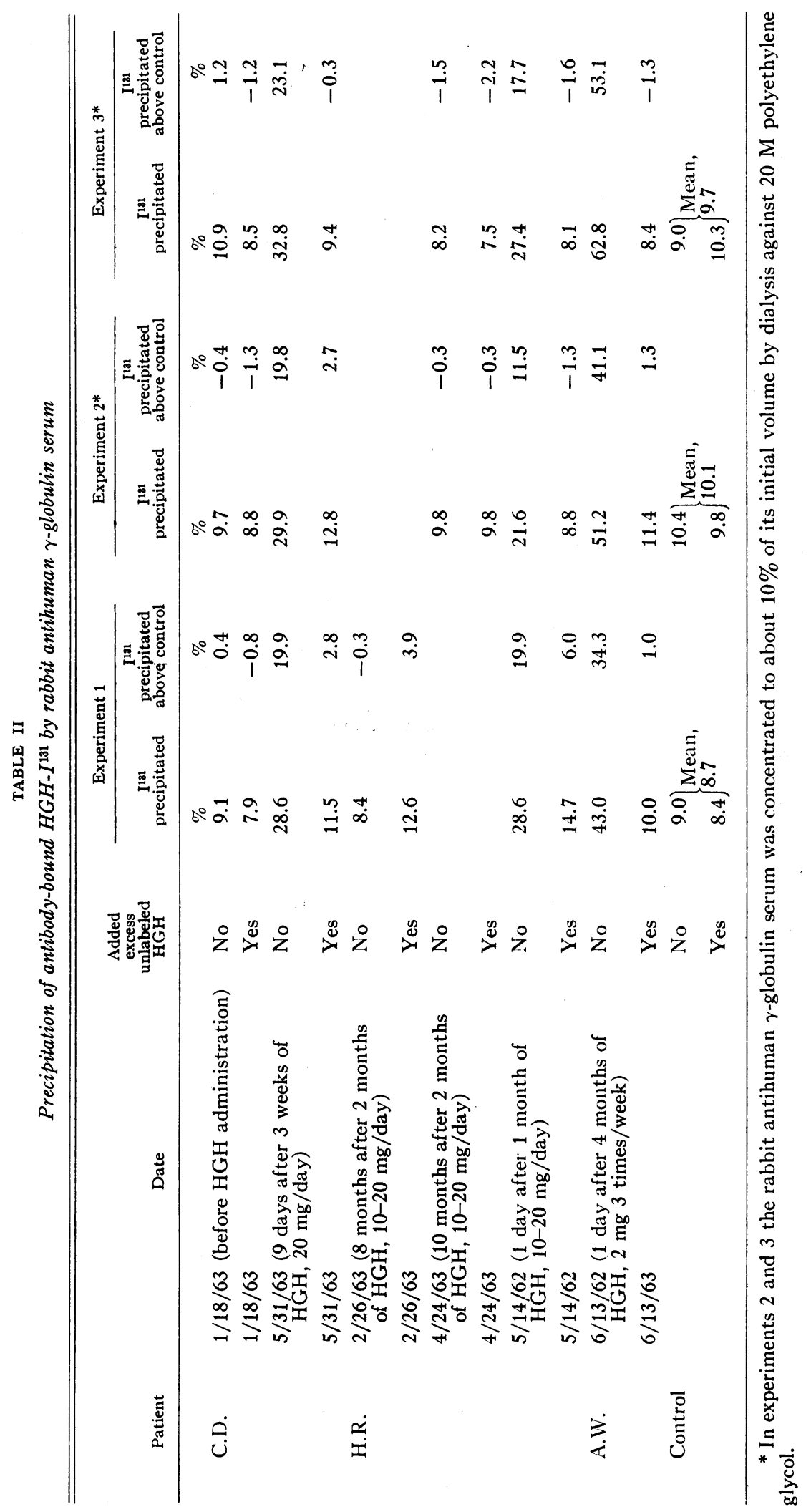


which resulted in dilution of the $\mathrm{HGH}$-anti-HGH complexes and dissociation of $\mathrm{HGH}$ from its antibody before precipitation by anti-antibody.

In all the systems used, the binding of $\mathrm{HGH}$ $\mathrm{I}^{131}$ to the $\gamma$-globulins was readily inhibited, competitively and specifically, by the addition of unlabeled hormone (Figures 4, 5, and 6; Table II).

In contrast, the nonspecific binding of damaged HGH-I ${ }^{131}$ to plasma proteins, particularly $\alpha$ - and $\beta$-globulins, as determined by paper chromatoelectrophoresis or agar gel immunoelectrophoresis, was not affected by the presence of an excess of unlabeled HGH. Dissociation of HGH-I ${ }^{131}$ from antibody occurred rapidly when the antibody concentration was decreased ten times by dilution, and when a large excess of unlabeled HGH was added to a mixture of HGH-I ${ }^{131}$ and antibody (Figure 7 ), suggesting that the antibodies bound $\mathrm{HGH}$ with a weak energy.

Peak HGH-binding capacities in the two adult subjects were $0.3 \mu \mathrm{g}$ per $\mathrm{ml}$ (C. D.) (Figure 6) and $0.5 \mu \mathrm{g}$ per $\mathrm{ml}$ (H. R.), respectively. One of

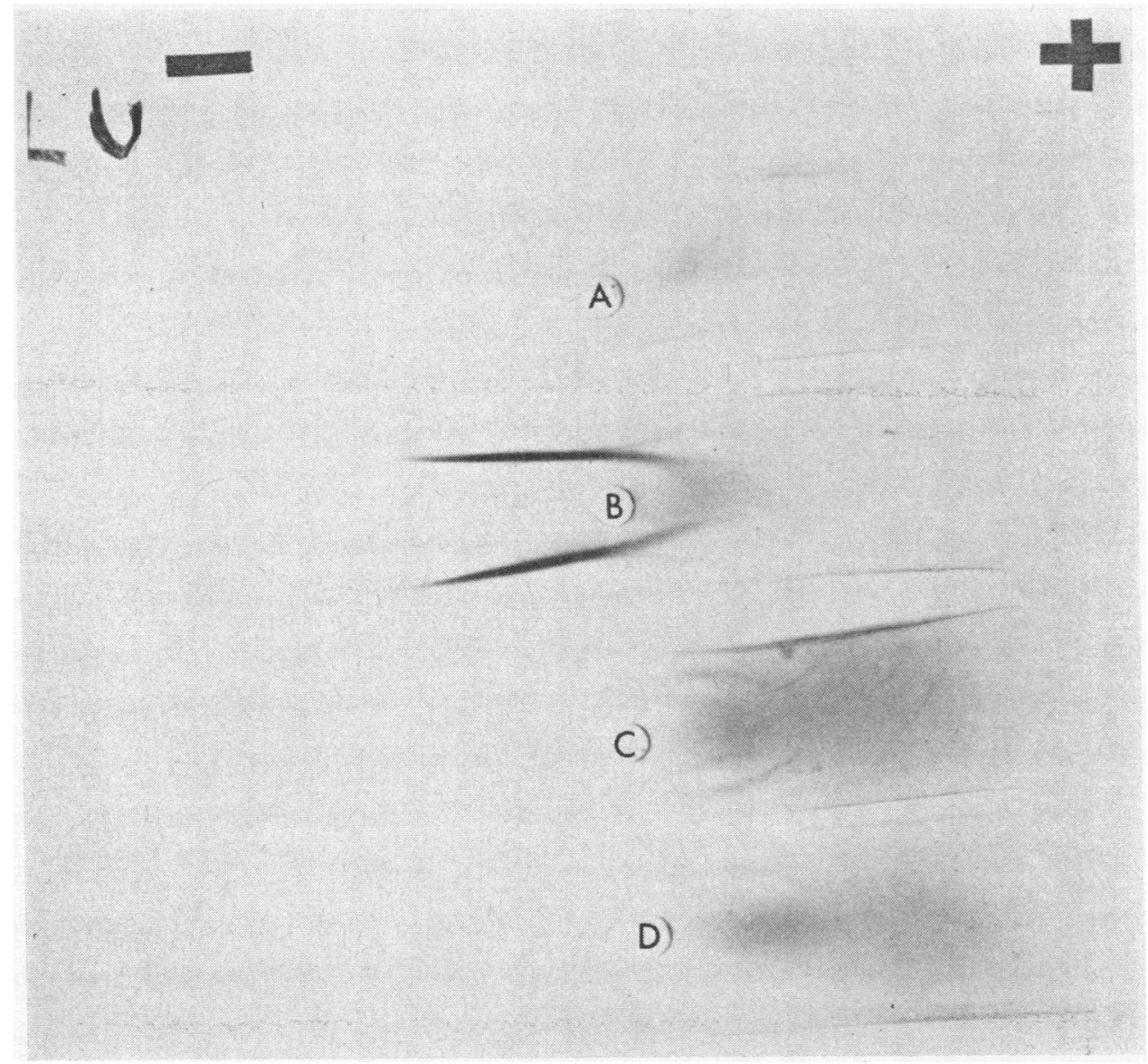

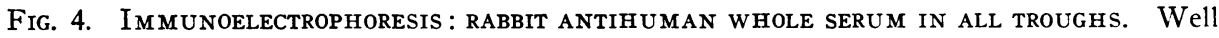
A : HGH-I ${ }^{131}$ in plasma from patient C. D. after HGH therapy plus large excess of unlabeled $\mathrm{HGH}$. Well B: Same as A, but no unlabeled hormone. Well C: $\mathrm{HGH}-\mathrm{I}^{131}$ in plasma from C. D. before $\mathrm{HGH}$ therapy. Well D: same as $\mathrm{C}$ plus large excess of unlabeled HGH. Note marked precipitate of radioactivity in $\boldsymbol{\gamma}$-globulin region in $\mathrm{B}$ and the absence of precipitate in the presence of excess unlabeled HGH (A). There is a small amount of nonspecific binding of radioactivity to all plasma proteins in all cases, but excess of unlabeled HGH does not competitively inhibit the nonspecific binding. Identical amounts of $\mathrm{HGH}-\mathrm{I}^{131}$ were placed in all wells. The amount of radioactivity precipitated with the $\gamma$-globulins of the control serum represents less than $2 \%$ of the total HGH-I ${ }^{15}$ added. The amount bound to all the plasma proteins in the control serum was less than $10 \%$. 


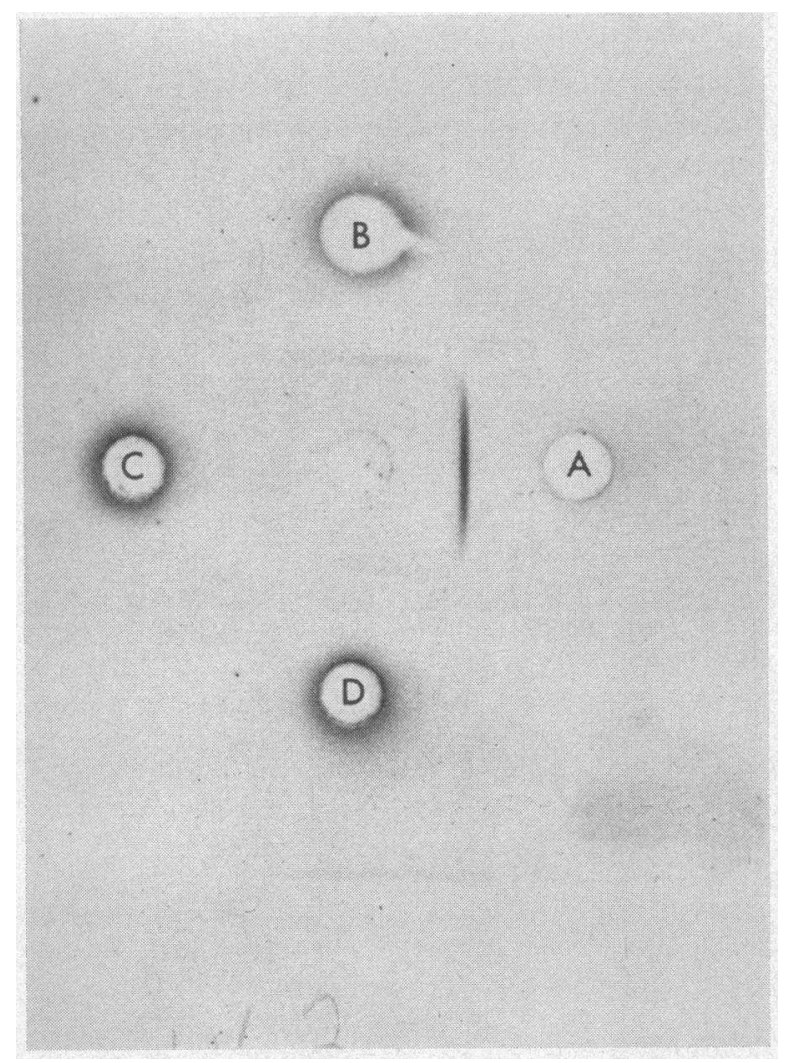

Fig. 5. ImMUNOdiffusion: RABbit antihuman $\boldsymbol{\gamma}$ GLOBULIN IN CENTER WELL. Well A: HGH-I ${ }^{131}$ in plasma of A. W. Well B: HGH-I ${ }^{131}$ in plasma of A. W. plus excess unlabeled $\mathrm{HGH}$. Well $\mathrm{C}$ : $\mathrm{HGH}-\mathrm{I}^{131}$ in control plasma. Well D: HGH-I ${ }^{131}$ in control plasma plus excess unlabeled $\mathrm{HGH}$.

the children (A. W.) tested had a binding capacity of over $4.0 \mu \mathrm{g}$ per $\mathrm{ml}$ of plasma.

Local or systemic allergic reactions were not observed. Tests for skin sensitivity were not performed.

\section{Discussion}

HGH- ${ }^{131}$ in the plasma of subjects with a previous history of $\mathrm{HGH}$ therapy is bound to a protein with the characteristic electrophoretic mobility of a $\gamma$ - or inter $\beta$ - $\gamma$-globulin, and is then precipitable with rabbit antihuman gamma globulin. That this binding protein is an antibody specific for $\mathrm{HGH}$ is suggested by 1 ) the absence of such binding in the plasma of subjects never treated with $\mathrm{HGH}, 2$ ) the slow fall in concentration of the globulin after cessation of HGH therapy and the prompt rise after resumption of such therapy, and 3) the inhibition and reversal of $\mathrm{HGH}-\mathrm{I}^{131}$ binding by excess unlabeled $\mathrm{HGH}$.
Conti and associates (16), using hemagglutination inhibition techniques, have reported circulating antibodies to $\mathrm{HGH}$ in hypopituitary dwarfs not treated with $\mathrm{HGH}$ and in acromegalic subjects after pituitary irradiation by yttrium ${ }^{90}$ implants. They interpreted these results as indicating an autoimmune phenomenon. Henneman and co-workers (17) and Laron (18), using precipitation techniques, Grumbach and Kaplan (19), using hemagglutination inhibition techniques, and Aarskog (20), using unspecified serologic methods, found no detectable antibody in sera of patients treated with repeated doses of HGH. Recently Trafford, Lillicrap, and Lessof (21) reported the detection, by the hemagglutination method, of $\mathrm{HGH}$ antibodies in the plasma of two of four children treated with $\mathrm{HGH}$. By a similar method Széky, Hässig, and Prader (22) found antibodies in one of seven treated subjects. However, the hemagglutination method is subject to falsely positive reactions and cannot be relied upon for evidence of specific antibody to a single substance, since the method does not identify the antigen and antibody responsible for the reaction. For example, a small contaminant, present even at less than $1 \%$ of the content of the immunizing preparation, if potently antigenic, might induce the formation of antibodies capable of completely agglutinating the tanned red cells exposed to the antigenic mixture and therefore coated with both $\mathrm{HGH}$ and contaminant. In contrast, the $\mathrm{HGH}-\mathrm{I}^{131}$ method allows specific identification of the antigen reacting with the antibody. Once it has been shown that a significant percentage of the labeled material is HGH (23), the demonstration that the bulk of labeled material is bound to antibody clearly reveals the presence of antibodies specific for $\mathrm{HGH}$. In general, techniques utilizing radioisotopically labeled hormone afford greater specificity and sensitivity than other methods for demonstrating both precipitating and nonprecipitating antibody.

The formation of antibody to human growth hormone in normal human subjects suggests one of two possibilities: 1) Some structural difference may exist between the administered hormone and the endogenous circulating hormone, or 2) no such difference exists, but during extraction and purification a small fraction of the administered preparation of hormone was altered and 
thereby endowed with an antigenic potency not present in the native molecule.

With reference to the first of these alternatives a structural difference may be present for one of several reasons. $\mathrm{HGH}$ as it exists in the pituitary gland may be different from the hormone that is released into the blood. Pituitary $\mathrm{HGH}$, like thyroglobulin, may not be a normal plasma constituent and therefore might be antigenic. Alternatively, the chemical methods used in the storage of pituitary glands and in the extraction and purification of hormones may produce molecular modifications. Experiments in which circulating hormone was compared with extracted pituitary hormone by a quantitative immunochemical procedure using rabbit antibodies to HGH (23) provide no evidence that the administered hormone differs significantly from the endogenous circulating hormone. Extracted pituitary hormone and endogenous plasma hormone reacted identically (23). Although this observation does not prove identity of pituitary and plasma hormones, similar immunochemical methods are at times capable of readily detecting different immunologic reactivities among various mammalian insulins that differ only in a single amino acid (24). Also, changes in growth hormone may occur on storage alone or in the intramuscular injection site as a result of proteolytic changes due to enzymes present as contaminants, or individual genetic differences in HGH may exist, as has been demonstrated for haptoglobins and transferrins.

With reference to the second alternative, it is sufficient to indicate that only a very minute fraction of the administered HGH need be so altered as to provide antigenic stimulation for the formation of antibodies that might crossreact with intact or native $\mathrm{HGH}$. Milgrom and Witebsky

PATIENT: C.D.
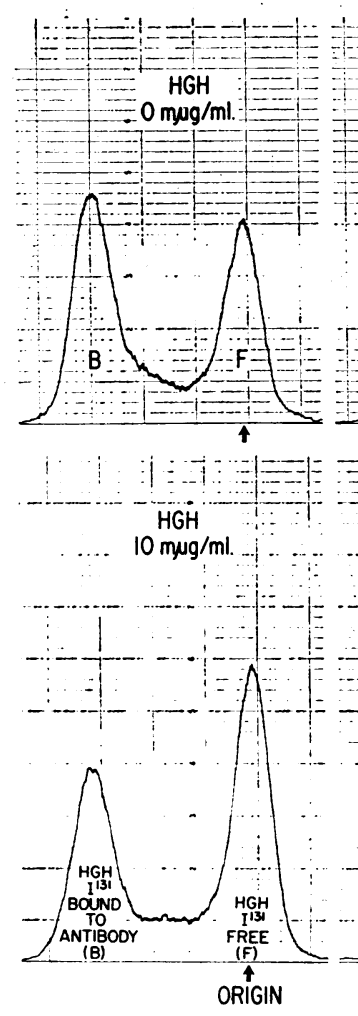

Fig. 6. Estimation of HGH-binding capacity of HGH antibodies in plasma of C. D. On left are chromatoelectrophoretograms of a mixture of $\mathrm{HGH}-\mathrm{I}^{131}$ in plasma (diluted 1:5) plus varying quantities of unlabeled $\mathrm{HGH}$ as indicated. The ratio, bound/free $\mathrm{HGH}-\mathrm{I}^{131}$, is plotted as a function of total $\mathrm{HGH}$ bound to antibody (right). The binding capacity of the plasma for $\mathrm{HGH}$ is given by the extrapolation of the curve to the horizontal axis.
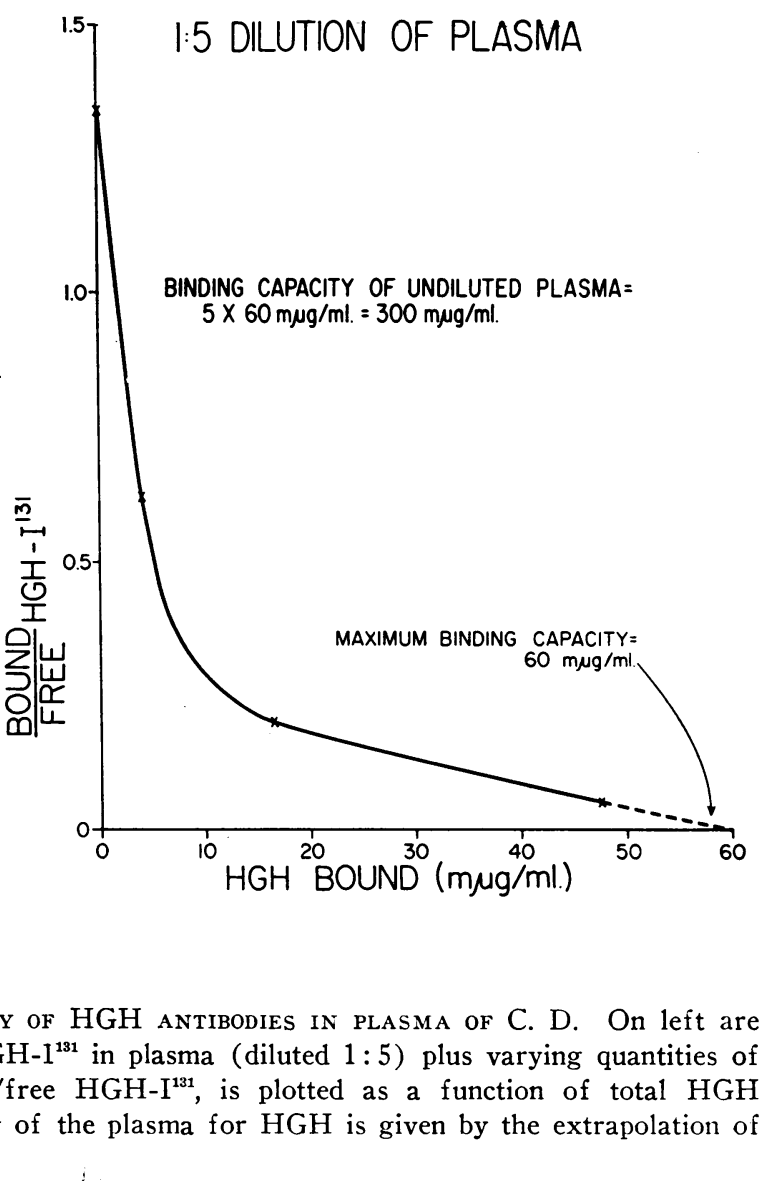


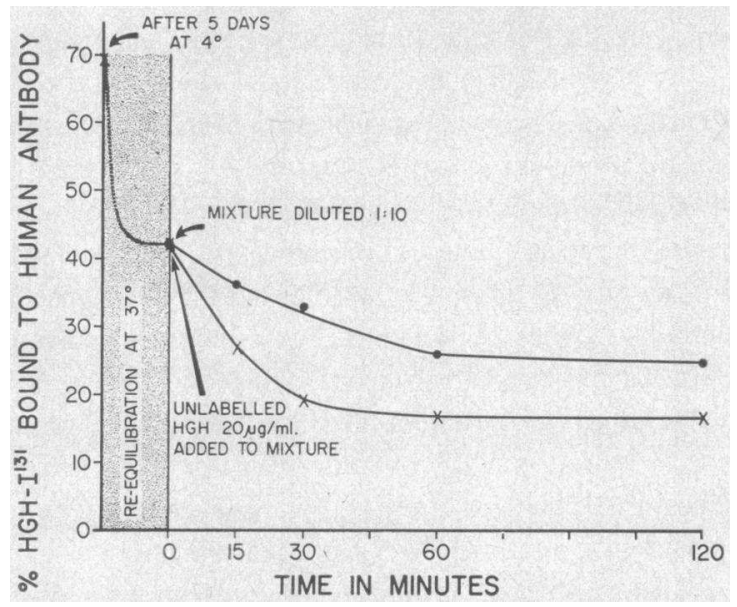

Fig. 7. Dissociation of HGH-I ${ }^{131}$ FROM HUMAN ANTI-HGH ANTIBODy. After incubation of HGH-I $\mathrm{I}^{131}$ in a $1: 5$ dilution of plasma for 5 days at $4^{\circ} \mathrm{C}$, the tubes were placed in a water bath at $37^{\circ}$. After re-equilibration, one portion of the mixture was diluted tenfold, and a large excess of $\mathrm{HGH}(20 \mu \mathrm{g}$ per $\mathrm{ml})$ was added to another portion of the mixture. Samples of both mixtures were then periodically examined by chromatoelectrophoresis at $4^{\circ} \mathrm{C}$ to determine the percentage of HGH-I ${ }^{131}$ remaining bound to antibody as a function of time.

(25) have reported that precipitated and frozen autologous $\gamma$-globulin is antigenic in the rabbit. Results of similar significance have been reported by McCluskey, Miller, and Benacerraf (26).

Several investigators $(19,20,27,28,29)$ have reported decreased patient responsiveness to $\mathrm{HGH}$ with continued administration. The demonstration that HGH-binding antibodies may result from the administration of $\mathrm{HGH}$ may explain some of the resistance to therapy. In the two adult patients reported here the gross metabolic responses to $\mathrm{HGH}$ were not significantly different as a result of antibody formation. There was also no obvious resistance to HGH therapy in the children who had antibody to HGH. Binding capacities in the range demonstrated by the two adults are unlikely to result in the inactivation of enough injected $\mathrm{HGH}$ to diminish detectably the metabolic response to the hormone. The $4 \mu \mathrm{g}$ per $\mathrm{ml}$ binding capacity of the plasma of one of the children, however, might be clinically significant. On the other hand, a high concentration of an antibody that binds $\mathrm{HGH}$ with a weak energy might actually have a beneficial effect by protecting the hormone from rapid destruction in the body and allowing its release slowly between injections.

Other potential effects of $\mathrm{HGH}$ antibodies in man remain to be assessed. Whereas, in the absence of endogenous HGH secretion, the only concern is the possible development of resistance to therapy, the possibility of antigen-antibody reactions within the cells of the anterior pituitary in persons with residual potential secretion of $\mathrm{HGH}$ must be considered but not necessarily feared. The almost universal development of insulin antibodies in persons treated with insulin (10) (human insulin has been shown to react with such antibodies) (11,30) has not only failed to produce drastic effects (except for relatively infrequent cases of insulin allergy and insulin resistance) but is also compatible with persistent excellent insulin-secretory activity (31).

The virtual disappearance of $\mathrm{HGH}$ antibody after discontinuation of $\mathrm{HGH}$ therapy in one of the normal subjects studied here suggests that a brief immunization period need not result in the permanent production of antibody. This observation suggests also that endogenous plasma HGH secretion (which presumably remained unimpaired after antibody formation) did not continue the antigenic stimulus. The consequences of much more prolonged courses of therapy merit independent evaluation.

\section{Summary}

1) Antibodies to human growth hormone (HGH) in human subjects treated with $\mathrm{HGH}$ were demonstrated by incubation of plasma with $\mathrm{HGH}-\mathrm{I}^{131}$ and separation of antibody-bound and free $\mathrm{HGH}$ by chromatoelectrophoresis and electrophoresis on paper. The existence of antibodies was confirmed by immunodiffusion and immunoelectrophoresis on agar gel and by immunoprecipitation with rabbit antihuman gamma globulin.

2) HGH-binding capacities as high as $4 \mu \mathrm{g}$ per $\mathrm{ml}$ of plasma were observed.

3) The nature of $\mathrm{HGH}$ antigenicity in man is considered, and several possible explanations are discussed.

\section{Addendum}

Since the preparation of this manuscript, J. L. Touber, using $\mathrm{I}^{131}$-labeled $\mathrm{HGH}$, also reports (personal communication) antibodies to $\mathrm{HGH}$, detected on agar gel electrophoresis, in one of Prader's cases (29) treated with HGH. 


\section{Acknowledgments}

The authors thank Drs. Melvin Grumbach, Selna Kaplan, Ernest Schwartz, and Edna Sobel for sera used in this study. We are also indebted to the Department of Medical Illustration for the figures.

\section{References}

1. Li, C. H., and H. Papkoff. Preparation and properties of growth hormone from human and monkey pituitary glands. Science 1956, 124, 1293.

2. Raben, M. S. Preparation of growth hormone from pituitaries of man and monkey. Science 1957, 125, 883.

3. Beck, J. C., E. E. McGarry, I. Dyrenfurth, and E. H. Venning. Metabolic effects of human and monkey growth hormone in man. Science 1957, $125,884$.

4. Pearson, O. H., M. B. Lipsett, E. Greenberg, and B. S. Ray. Effects of human growth hormone in hypophysectomized patients. Presented at Thirtyninth Annual Meeting of Endocrine Society, New York, May 30-June 1, 1957.

5. Bergenstal, D. M., H. A. Lubs, L. F. Hallman, J. Patten, H. J. Levine, and C. H. Li. Metabolic effects of human and monkey growth hormone in man (abstract). J. Lab. clin. Med. 1957, 50, 791.

6. Hayashida, T., and C. H. Li. An immunological investigation of human pituitary growth hormone. Science 1958, 128, 1276.

7. Read, C. H., and D. B. Stone. An immunological assay for minute amounts of pituitary growth hormone. J. Dis. Child. 1958, 96, 538.

8. Hunter, W. M., and F. C. Greenwood. Preparation of iodine-131 labelled human growth hormone of high specific activity. Nature (Lond.) 1962, 194, 495.

9. Smithies, O. Zone electrophoresis in starch gels and its application to studies of serum proteins. Advanc. Protein Chem. 1959, 14, 65.

10. Berson, S. A., R. S. Yalow, A. Bauman, M. A. Rothschild, and K. Newerly. Insulin- ${ }^{181}$ metabolism in human subjects: demonstration of insulin binding globulin in the circulation of insulin treated subjects. J. clin. Invest. 1956, 35, 170.

11. Berson, S. A., and R. S. Yalow. Preparation and purification of human insulin- $\mathrm{I}^{131}$; binding to human insulin-binding antibodies. $\mathrm{J}$. clin. Invest. 1961, 40, 1803.

12. Yalow, R. S., and S. A. Berson. Immunoassay of endogenous plasma insulin in man. J. clin. Invest. 1960, 39, 1157.

13. Oudin, J. Specific precipitation gels and its application to immunochemical analysis. Meth. med. Res. 1952, 5, 335.
14. Scheidegger, J. J. Une micro-méthode de l'immunoelectrophorèse. Int. Arch. Allergy 1955, 7, 103.

15. Feinberg, R. Detection of non-precipitating antibodies coexisting with precipitating antibodies using $\mathrm{I}^{\text {1s1 }}$ labeled antigen. Fed. Proc. 1954, 13, 493.

16. Conti, C., L. Sereno, L. Luchetti, O. Recchia, and A. Isidori. Detection of anti-STH antibodies in man. Folia endocr. (Roma) 1962, 15, 163.

17. Henneman, P. H., A. P. Forbes, M. Moldawer, E. F. Dempsey, and E. L. Carroll. Effects of human hormone in man. J. clin. Invest. 1960, 39, 1223.

18. Laron, Z. Discussion of Prader, A., and R. Illig. Use of anabolic agents in disorders of growth in Protein Metabolism. Berlin, Springer-Verlag, 1962, p. 399.

19. Grumbach, M., and S. Kaplan. Personal communication (S. Kaplan).

20. Aarskog, D. Human growth hormone in dwarfism since birth. Amer. J. Dis. Child. 1963, 105, 368.

21. Trafford, J. A. P., D. A. Lillicrap, and M. H. Lessof. Human growth hormone in pituitary infantilism. Lancet 1963, 1, 1128.

22. Széky, J., A. Hässig, and A. Prader. Über Antikörper gegen menschliches Wachstumshormon vom Typus Raben bei Patienten mit Zwergwuchs. Helv. paediat. Acta 1962, 17, 411.

23. Glick, S. M., J. Roth, R. S. Yalow, and S. A. Berson. Immunoassay of human growth hormone in plasma. Nature (Lond.) 1963, 199, 784.

24. Berson, S. A., and R. S. Yalow. Species-specificity of human anti-beef, pork insulin serum. J. clin. Invest. 1959, 38, 2017.

25. Milgrom, F., and E. Witebsky. Studies on the rheumatoid and related serum factors I. Autoimmunization of rabbits with gamma globulin. J. Amer. med. Ass. 1960, 174, 56.

26. McCluskey, R. T., F. Miller, and B. Benacerraf. Sensitization to denatured autologous gamma globulin. J. exp. Med. 1962, 115, 253.

27. Henneman, P. H., and D. H. Henneman. Human growth hormone. A preliminary report. Diabetes 1960, 9, 272.

28. Raben, M. S., P. R. Minton, M. L. Mitchell, and H. Juarez-Penalva. Metabolic effects of growth hormone in man in Protein Metabolism. Berlin, Springer-Verlag, 1962, p. 121.

29. Prader, A., and R. Illig. Use of anabolic agents in disorders of growth in Protein Metabolism. Berlin, Springer-Verlag, 1962, p. 383.

30. Arquilla, E. R., and A. B. Stavitsky. Evidence for the insulin-directed specificity of rabbit anti-insulin serum. J. clin. Invest. 1956, 35, 467.

31. Yalow, R. S., and S. A. Berson. Immunoassay of plasma insulin in man. Diabetes 1961, 10, 339. 